\title{
Visual ecology of aphids-a critical review on the role of colours in host finding
}

\author{
Thomas Felix Döring · Lars Chittka
}

Received: 10 November 2006/ Accepted: 15 December 2006/Published online: 2 March 2007

(C) Springer Science+Business Media B.V. 2007

\begin{abstract}
We review the rich literature on behavioural responses of aphids (Hemiptera: Aphididae) to stimuli of different colours. Only in one species there are adequate physiological data on spectral sensitivity to explain behaviour crisply in mechanistic terms. Because of the great interest in aphid responses to coloured targets from an evolutionary, ecological and applied perspective, there is a substantial need to expand these studies to more species of aphids, and to quantify spectral properties of stimuli rigorously. We show that aphid responses to colours, at least for some species, are likely based on a specific colour opponency mechanism, with positive input from the green domain of the spectrum and negative input from the blue and/ or UV region. We further demonstrate that the usual yellow preference of aphids encountered in field experiments is not a true colour preference but involves additional brightness effects. We discuss the implications for agriculture and sensory ecology, with special respect to the recent debate on autumn leaf colouration. We illustrate that recent evolutionary theories concerning aphid-tree interactions imply
\end{abstract}

Handling Editor: Robert Glinwood

T. F. Döring · L. Chittka

School of Biological and Chemical Sciences, Queen Mary

University of London, Mile End Road, E1 4NS London, UK

L. Chittka

e-mail: 1.chittka@qmul.ac.uk

T. F. Döring ( $₫)$

Aphid Biology Group, Division of Biology, Faculty of

Natural Sciences, Imperial College London, Silwood Park

Campus, Ascot, Berkshire SL5 7PY, UK

e-mail: t.doering@imperial.ac.uk far-reaching assumptions on aphid responses to colours that are not likely to hold. Finally we also discuss the implications for developing and optimising strategies of aphid control and monitoring.

Keywords Aphid A Aphididae - Autumn colouration · Behaviour · Colour · Colour opponency · Hemiptera . Host finding $\cdot$ Pest control · Vision

\section{Introduction}

Everyone who cares for plants knows aphids (Hemiptera: Aphididae). These small and gentle insects with famously powerful reproductive potential are of immense importance both in agriculture and horticulture (Miles 1989), as well as in non-agricultural ecosystems (Stadler et al. 1998; Wimp and Whitham 2001). They are major pests in many crop and fruit species, because they remove plant assimilates (Miles 1989), induce galls (e.g. Brown et al. 1991), transmit plant viruses (Sylvester 1989), and excrete honey dew that acts as a growing medium for unwanted fungi (Rabbinge et al. 1981; Fokkema et al. 1983). However, as producers of honeydew, some aphid species also provide a resource eagerly sought by bee-keepers for the production of premium forest honey (Bauer-Dubau and Scheurer 1993).

The interest for the host finding behaviour of aphids, and for the biotic and abiotic factors that drive it, was often rooted in the area of virus vector control. For example, Volker Moericke, who in the 1950s and 1960s was the most productive researcher in investigating aphid responses to colours and the role of colours for host finding in aphids, had begun his career with a thesis on the colonisation of potato by the aphid 
Myzus persicae with the motivation to contribute to the progress of potato virus control (Moericke 1941). A later paper on the response of alighting aphids to colours (Moericke 1952) was embedded in a potato virus control project.

Host finding in alate (winged) aphids is a complex behaviour that is closely linked to migration and the function of dispersal. The classic and often-cited concept of host finding behaviour in aphids (Moericke 1955a) distinguishes four overlapping behavioural stages (the teneral period; the distance flight or migration flight; the attacking flight, when the aphid repeatedly lands and probes on plants; and the final settling period), each corresponding to a certain behavioural 'mood' (motivation). For a different concept of aphid host finding behaviour, see Kennedy (1966) and works cited there.

Many stimuli and environmental conditions have been found to influence flight (Broadbent 1949; Johnson 1958; Kring 1972), and landing or probing response during the 'attacking flight', including tactile (Hennig 1963), visual (see below) and olfactory cues. Olfactory stimuli, such as plant volatiles, had long been considered to be of low importance (Kennedy 1950; Kennedy et al. 1959a, b), but it is now clear that odours play an important role in host finding of aphids (e.g., Petterson 1970; Chapman et al. 1981; Hardie et al. 1994; Powell et al. 1995; Park et al. 2000). Interactions between olfactory and visual stimuli have also been reported (Dilawari and Atwal 1989; Hardie et al. 1996) and this area clearly deserves further exploration.

Additional interest in the role of colours in host selection of aphids was recently created by the debate on autumn leaf colouration as a potential signal or cue to aphids (e.g., Sinkkonen 2006), initiated by a paper from Hamilton and Brown (2001); for a review see Manetas (2006). However, in this debate, the perspective of colour perception by the aphids appears to have been largely neglected. Unfortunately, the rich literature on behavioural responses of aphids to colours has not entered the discussion of the adaptive significance of autumn leaf colouration yet. Moreover, the sensory aspects, especially concerning the progress made in physiology and conceptualisation of colour vision have largely been ignored in the agricultural (as well as the evolutionary) literature on aphid responses to colour. We therefore describe the theoretical and technical concepts necessary when setting up or interpreting colour vision experiments with aphids. Thus, this review may serve as a bridge between the agricultural and the biological shore and will hopefully give both ecologists and agricultural entomologists new insights into the intriguing visual world of aphids.
The physiological basis for the perception of colours in aphids

The basic receptor units for the perception of light are photoreceptor cells, which, in insects, are located in the retina of the compound eye and in the ocelli (Menzel 1979; Menzel and Backhaus 1991; Briscoe and Chittka 2001). Additional extraocular photoreceptors which serve circadian clocks have also been found in aphids (Hardie and Nunes 2001) but are disregarded in this paper. A photoreceptor acts as a photon counter, so that it cannot distinguish between photons of different wavelengths. However, the light absorption of photoreceptor pigments depends on the wavelength, so that the strength of the response from a cell containing the pigment varies with wavelength for stimuli of equal intensity. This wavelength dependency of the photoreceptor's capability to count photons can be plotted as its spectral sensitivity function (Fig. 1). Thus, a bright light with a high number of photons at a wavelength far away from the sensitivity peak may cause the same physiological response in the photoreceptor cell as a dim light at the peak sensitivity wavelength. A system based on only one type of receptor could therefore not distinguish colours. Many insects studied so far have three types of photoreceptor cells in their compound eyes, with one type showing maximal sensitivity in the green, a second type with the peak in the blue and the third type with a peak in the ultraviolet (Briscoe and Chittka 2001). In fact, it has been suggested that the ancestor of pterygote insects was equipped with these three types of photoreceptors (Chittka 1996a). Many species of insects, however, show variations from this basic trichromatic system, with some having four or more spectral receptor types (Arikawa et al. 1987; Briscoe and Chittka 2001).



Fig. 1 Tentative spectral sensitivities of three modelled types of photoreceptors of Myzus persicae. Model after Stavenga et al. (1993) 
There is still very limited information on photoreceptor sensitivities in herbivorous insects, as already lamented by Prokopy and Owens (1983). A reason for the scarcity of physiological information on aphids, in particular, is that the appropriate techniques are difficult to apply because the animals are so small and soft, which makes inserting microelectrodes into single cells of their eyes exceptionally difficult.

The green peach aphid (Myzus persicae Sulzer, Hemiptera: Aphididae) is the only aphid species that has been physiologically tested for spectral sensitivity so far (Kirchner et al. 2005), using extracellular recordings (ERG). The overall peak sensitivity of the eye was found at $530 \mathrm{~nm}$. This work clearly showed that there are more than two photoreceptors in this aphid species. Besides a putative green receptor with a maximum sensitivity at $530 \mathrm{~nm}$, a UV receptor with a peak at 320-330 nm was found, and a blue receptor with a peak sensitivity somewhere between $440 \mathrm{~nm}$ and $480 \mathrm{~nm}$ was also necessary to explain the obtained results. A red receptor is absent in $M$. persicae.

Given that the knowledge of the spectral sensitivities of photoreceptors is of central importance for the understanding of any behavioural responses to colours, it would be extremely desirable to obtain such data for more species, and to get even more detailed data for $M$. persicae. Other herbivorous insects appear to be roughly similar to $M$. persicae, in that they too possess UV, blue and green receptors and lack red receptors. Intracellular recordings showed sensitivity peaks at 360-370 nm, 440-450 nm, and $530 \mathrm{~nm}$ in the potato beetle Leptinotarsa decemlineata Say (Döring and Skorupski 2007), the orthopteran herbivore Locusta migratoria L. (Vishnevskaya and Shura-Bura 1990) and the herbivorous caterpillar of the butterfly Trabala vishnou Lefebur (Lin et al. 2002). It remains to be determined whether the similarities are the result of ecological adaptation or common ancestry, and whether the subtle differences noted between species are statistically and ecologically meaningful.

The set of aphid photoreceptors (UV, blue, green) differs strongly from that of humans, which have blue, green and red receptors for photopic vision, as well as additional rods for scotopic vision (e.g., Dartnall et al. 1983). Because insect and human colour vision are so fundamentally different, any classification of colours that is based on human colour vision (e.g., Hamilton and Brown 2001; Archetti and Leather 2005; Dominy et al. 2002) could potentially be misleading when discussing possible effects of colours on insects or any other animals.
From photoreceptor spectral sensitivity to behavioural responses to colour

When the spectral sensitivities of an animal's photoreceptors are known, it is possible to quantitatively predict the signal that these receptors will send to the brain when viewing a particular target. When light reflected from an object (a stimulus s) meets the aphid's eye, the excitation $\mathrm{E}$ of each photoreceptor $\mathrm{R}$ can be calculated, if the reflectance spectrum $I_{s}(\lambda)$ of the stimulus; the sensitivity function $S_{R}(\lambda)$ of the photoreceptor; the illumination spectrum $\mathrm{D}(\lambda)$; and the reflectance spectrum $\mathrm{I}_{\mathrm{b}}(\lambda)$ of the background $\mathrm{b}$ against which the stimulus appears are known; then

$\mathrm{E}_{\mathrm{R}}=\mathrm{P}_{\mathrm{R}} /\left(\mathrm{P}_{\mathrm{R}}+1\right)$ with

$\mathrm{P}_{\mathrm{R}}=\int \mathrm{I}_{\mathrm{s}}(\lambda) \mathrm{S}_{\mathrm{R}}(\lambda) \mathrm{D}(\lambda) \mathrm{d} \lambda / \int \mathrm{I}_{\mathrm{b}}(\lambda) \mathrm{S}_{\mathrm{R}}(\lambda) \mathrm{D}(\lambda) \mathrm{d} \lambda$

where $\mathrm{P}_{\mathrm{R}}$ is the amount of light absorbed by photoreceptor $\mathrm{R}$. Note that the excitation $\mathrm{E}_{\mathrm{R}}$ of the photoreceptor $\mathrm{R}$ is a non-linear function of the light absorbed (Eq. 1). $\mathrm{E}_{\mathrm{U}}, \mathrm{E}_{\mathrm{B}}$ and $\mathrm{E}_{\mathrm{G}}$ are the excitations of the UV, blue and green receptor for a trichromatic insect.

As an example, consider the stimuli from spindle leaves (Euonymus europaeus L., the winter host of the black bean aphid, Aphis fabae Scopoli), leaves from the mountain ash (Sorbus aucuparia L., host of several aphid species, including Dysaphis sorbi Kaltenbach), and from bird cherry (Prunus padus L., winter host of Rhopalosiphum padi L.). The colours of these leaves appear green $(\mathrm{g})$, yellow (y), and red (r) to humans. Figure 2 shows the reflectance spectra $I_{s}(\lambda)$ of these stimuli measured with a spectrophotometer. In order to calculate the photoreceptor excitations that these leaves elicit, we further need an illumination spectrum $\mathrm{D}(\lambda)$. We use D65 standard spectrum, which is a daylight spectrum of the sun at noon (cf. Siddiqi et al. 2004). As a background reflectance spectrum $I_{b}(\lambda)$ we choose a dark grey background of $20 \%$ reflectance intensity (cf. Döring and Skorupski 2007). The sensitivity functions $S_{R}(\lambda)$ of the three photoreceptors are modelled according to Stavenga et al. (1993), with the peak sensitivities of the green and the UV receptor derived from Kirchner et al. (2005) (see above) and the blue receptor sensitivity peak (which has been determined to lie between $440 \mathrm{~nm}$ and $480 \mathrm{~nm}$ ) set to $450 \mathrm{~nm}$. For each leaf, the corresponding excitations of the modelled UV, blue and green receptors (Fig. 1) are given in Fig. 3. For further discussion of these data see Section 'Behavioural preferences of aphids for coloured stimuli'. 


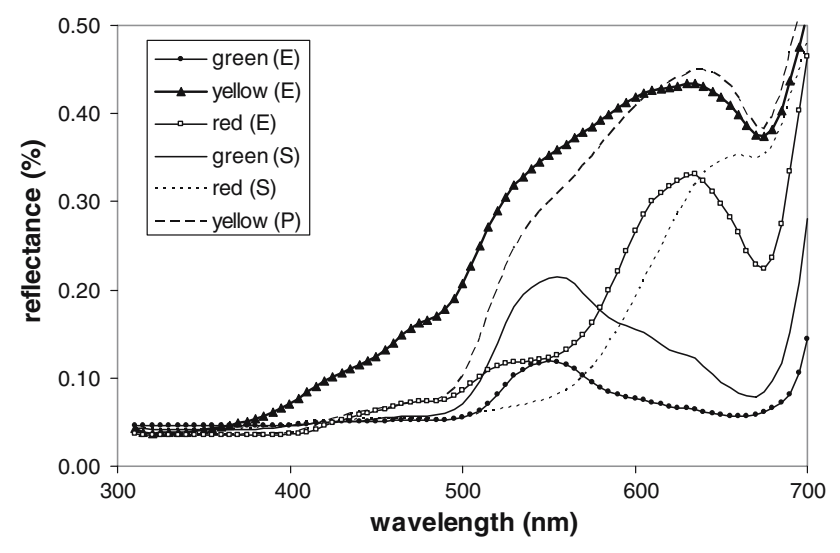

Fig. 2 Spectral reflectance of the upper side of variously coloured Euonymus europaeus (E), Sorbus aucuparia (S), and Prunus padus (P) leaves, seen as 'green', 'yellow' and 'red' by humans. Within the species leaves were taken from the same individual tree, in Göttingen Botanic Garden, Germany on 22 September 2006, and spectrometrically measured against a calibrated $\mathrm{BaSO}_{4}$ standard with a RAMSES ARC spectrometer from TriOs, Osnabrück, Germany, under a Xe arc lamp illumination

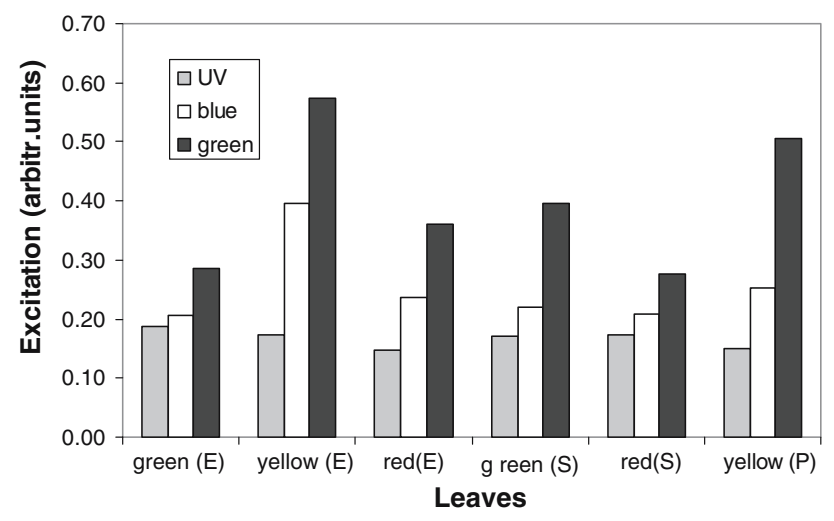

Fig. 3 Excitations of a putative set of photoreceptors (the set presented in Fig. 1) by stimuli of Euonymus europaeus (E), Sorbus aucuparia (S), and Prunus padus (P) leaves (from Fig. 2) which are seen against a grey background of $20 \%$ intensity, and illuminated by a D65 standard sunlight. See text for further details

To understand how the information from photoreceptors is integrated to form adaptive behaviour towards colour targets, we can use psychophysical tests that allow deduction of the colour processing mechanisms in an animal (Menzel and Backhaus 1991; Chittka et al. 1992). These mechanisms might differ strongly between insect orders (compare e.g. the system postulated for the honeybee (Menzel and Backhaus 1991) with that in a blowfly (Troje 1993). Therefore, extrapolation from one species to a distantly related one is hazardous.

Fortunately, however, there are suitable data from the same species of aphid (Myzus persicae) for which receptor data are available. Moericke (1950) did two experiments that indicate information integration from more than one spectral domain. In his first experiment, he sent sunlight through a prism and a slit to produce (nearly) monochromatic light. This was used to illuminate paper on which Moericke counted the number of probings (proboscis extension) done by $M$. persicae. He showed that the number of probings was highest in orange, yellow and green, but low on red and blue. Because green, yellow and orange all stimulate the aphids' green receptor, one might perhaps assume that the signal from this receptor alone might drive proboscis extension-but this is clearly not the case. Moericke (1950) also tested white targets, and found that these had little attraction for the aphids-even though the white targets contained even more intensity in the green domain of the spectrum than e.g. the green targets. This result also indicates that overall stimulus intensity is not the parameter that drives probing responses.

In the second experiment, Moericke observed aphids walking from an unattractive colour (e.g. blue) to grey paper, a type of paper that usually did not prompt the aphids to extend their proboscides. However, when grey was encountered after an unattractive colour, many aphids would respond by probing grey. The highest response was induced when aphids came from a blue shade with a dominant wavelength of $440 \mathrm{~nm}$. This suggests a successive colour contrast effect (Neumeyer 1981; Dyer and Neumeyer 2005) in Myzus persicae. This effect was also demonstrated for apterous Aphis fabae (Moericke 1979). Figure 4 shows a linear reproduction of the colour contrast experiments with $M$. persicae (Moericke 1950). His findings are clear evidence for a colour opponency mechanism, with negative input from a blue receptor and excitatory input from the green receptor. There may also be inhibitory input from the UV receptor, because Moericke (1955a, p. 50) later found that the catch in a yellow field trap was higher with an additional UV absorbing filter placed on top than without the filter. Thus, the appropriate opponent mechanism can be described by the equation:

$\mathrm{E}_{\mathrm{opp}}=-\mathrm{aE}_{\mathrm{U}}-\mathrm{bE} \mathrm{E}_{\mathrm{B}}+\mathrm{cE}_{\mathrm{G}}$

where $E_{U}, E_{B}$ and $E_{G}$ are again the receptor excitations in the UV, blue and green receptors, $E_{\text {opp }}$ is the relative excitation of the opponent mechanism, and a, $\mathrm{b}$ and $\mathrm{c}$ are weighting factors that remain to be determined. We will later see that the type of colour opponency postulated in Eq. 3 can explain many of the published behavioural responses of aphids to colours, including their well-known preference for yellow over 


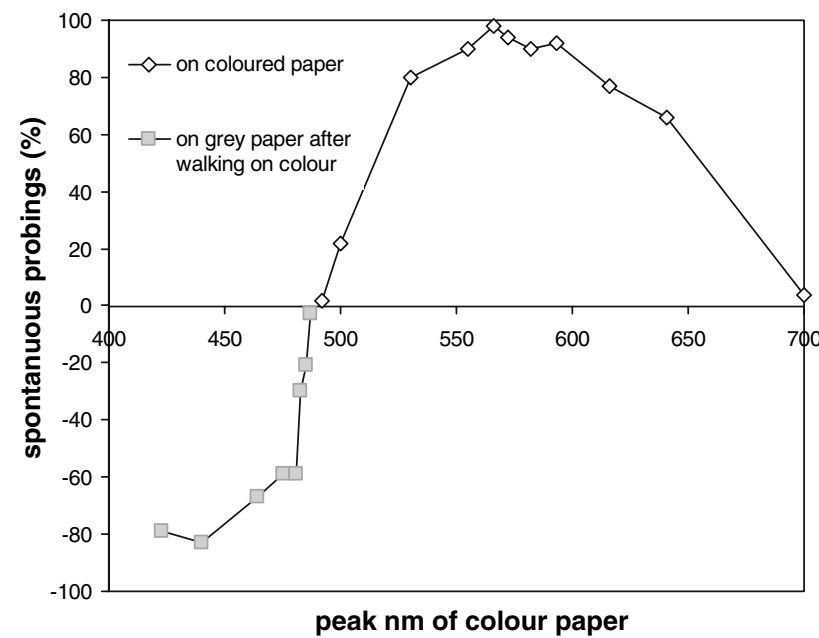

Fig. 4 Linear representation of data published by Moericke (1950, p. 270) with Myzus persicae. Probings on grey paper after walking on coloured paper have been assigned to a negative sign, probings on coloured paper without prior colour stimuli to positive sign, in order to mark the different experimental approaches. Further explanations see text (Section 'From photoreceptor spectral sensitivity to behavioural responses to colour')

green. Note that colour opponent cells of this type have indeed been found in the optic lobes of the honeybee by electrophysiological methods (Yang et al. 2004). Therefore, it would be highly desirable to attempt electrophysiological recordings from higher visual neurons in aphids.

In summary, the aphid $M$. persicae, has the basic mechanistic requirements for true colour vision: a minimum of two classes of spectral receptor types ( $M$. persicae has three) and at least one colour opponent mechanism to 'compare' inputs from different spectral domains (Menzel 1979; Goldsmith 1991; Chittka and Wells 2004). Such a mechanism is necessary to make responses to colour independent of intensity, a basic criterion for colour vision (Menzel 1979). It remains to be determined, however, whether this sensory-neural equipment is used to generate a true colour vision system, i.e. whether aphids see images in which objects have colour attributes. This could be tested exploring whether aphids can be trained to flexibly associate colour with unconditioned stimuli (such as rewards; Menzel 1979; Goldsmith 1994). If aphids fail this criterion, the data could be parsimoniously explained by assuming that aphids generate 'wavelength specific behaviour' (Menzel 1979; Goldsmith 1994). In other words, a colour opponent neuron of the type above might be directly connected to a motor circuit controlling proboscis extension, without the aphids actually seeing coloured images.
Although colour opponency is very likely for other aphid species than $M$. persicae according to a large number of behavioural experiments (see below), it remains to be tested for these species with more targeted methods. Apart from the suggested physiological characterisation of opponent colour neurons, which could pose considerable technical challenges, the simple successive colour contrast experiment done by Moericke (1950), if repeated with monochromatic lights and more species seems to be an elegant method to substantiate colour opponency in aphids.

\section{Behavioural preferences of aphids for coloured stimuli}

The effect of differently coloured stimuli on aphid behaviour was tested in a great number of experiments (Tables 1-3). However, due to the widely varying aims and different methods applied in the studies, many of them do not allow more than very cautious conclusions. The first study suggesting that aphids react differentially to spectral stimuli was published by Moore (1937) on aphid responses to coloured pesticides and dusts. However, in this investigation, the alighting response was not observed but only the number of aphid colonies, so that the possible effects on landing behaviour may be confounded with other effects unrelated to the aphid's behavioural response to colours. More importantly, colour was not separated from light intensity. Moericke (1952) compared various achromatic (grey, white and black) and chromatic stimuli regarding their effect on winged aphids in the field. Unfortunately, the species were not segregated, only one genus (Hyperomzyus) was shown separately. Here, the landing response to yellow was highest among the colours tested, and again, low for the achromatic stimuli.

This 'yellow preference' was backed by a large number of subsequent studies. Most tested aphid species responded more strongly to yellow stimuli than to green or red ones (Table 3), similar to several other phytophagous insects species (Prokopy and Owens 1983, p. 350). Because of this general attractiveness of yellow to aphids, yellow traps are widely used for monitoring of aphid flight activity (Moericke 1951; Rieckmann and Zahn 1998), and have been suggested for their control (Budnik et al. 1996). There was even a positive effect of yellow light on reproduction and survival of aphids when they were reared on artificial diets and illuminated with differently coloured lights (Auclair 1967).

How can the preference for 'yellow' be explained? Some researchers thought that the higher preference for yellow over green observed so frequently is due to 
Table 1. References for Table 3
${ }^{a}$ Catch 21-29. July 2004, in Hebenshausen, Germany, on plastic sheets sprayed with Soveurode ${ }^{\circledR}$ (Witasek, Austria) insect glue

\begin{tabular}{llll}
\hline Ref-nr. & Reference & Figure or table & Pages \\
\hline 1 & A'Brook (1973) & Fig. 1 (horizontal traps) & 266 \\
$2 \mathrm{a}$ & Boiteau (1990) & Table 1 & 940 \\
$2 \mathrm{~b}$ & Boiteau (1990) & Table 2 & 940 \\
3 & Burrows et al. (1983) & Table 2 & 206 \\
4 & Campbell (1991) & Table 1 & 96 \\
5 & Hardie (1989) & Figs. 1, 2 & $621-622$ \\
6 & Hardie et al. (1996) & Figs. 3, 4 & $101-102$ \\
7 & Hermoso et al. (1998) & Table 1 & 124 \\
8 & Hodgson and Elbakiet (1985) & Table 1 & 269 \\
9 & Kieckhefer et al. (1976) & Fig. 3A & 723 \\
10 & Kring (1967) & Table 3 & 1209 \\
11 & Moericke (1950) & Fig. 1 & 266 \\
12 & Moericke (1952) & Fig. 1 & 306 \\
13 & Moericke (1953) & Fig. 6 & 94 \\
$14 \mathrm{a}$ & Moericke (1955a) & Table 6, 8 & $44-45$ \\
$14 \mathrm{~b}$ & Moericke (1955a) & Table 13 & 53 \\
$14 \mathrm{c}$ & Moericke (1955a) & Fig. 7 & 68 \\
15 & Moericke (1969) & Fig. 1a & 527 \\
16 & Nottingham et al. (1991) & Fig. 2 & 226 \\
17 & Pelletier (1990) & Table 2 & 697 \\
18 & Pospísil (1963) & Fig. 1 & 96 \\
19 & Prasad and Lal (2001) & Table 4 & 289 \\
20 & Ždárek and Pospísil (1966) & Table 1 & $20-21$ \\
21 & TF Döring (unpubl.) & a & - \\
\hline & & & \\
\hline & & &
\end{tabular}

the higher reflectance in the green spectral domain of yellow than of green (Prokopy and Owens 1983). However this is unlikely to explain the phenomenon accurately. If this was so, almost any white or pink signal would be even more attractive than yellow, and this is clearly not the case. For example, Moericke (1952) varied the saturation of yellow by mixing different amounts of white to it; here, the highest number of aphids was found in the trap with the highest saturation, i.e. with the lowest amount of white. The point is that typical yellow (from a leaf (Shull 1929; Merzlyak et al. 1999) or a trap (Moericke 1955a, p. 59; Baldy and Rabasse 1983)) has a substantially higher reflectance in the longer wavelengths (green to red spectrum), but at the same time, is relatively low in the shorter wavelengths (UV to blue spectrum). Hence, an opponent channel that is of the $\left[\mathrm{U}^{-} \mathrm{B}^{-} \mathrm{G}^{+}\right]$type (see Eq. 3 above) would respond more strongly to yellow than to green, but less to white.

The possible role of the suggested colour opponent mechanisms is further illustrated by the rigorous study of Hardie (1989) on winged Aphis fabae colour responses. Here, monochromatic lights of different wavelengths in the visible spectrum were presented with varied light intensities. In the resulting behavioural efficiency curves, the peak response was not in the yellow but in the green, for both the summer and the autumn migrants. Because the intensity component was controlled in this experiment, this green peak is not a contradiction to the yellow preference observed elsewhere. Rather, the proposed opponent mechanism, here fed only by the inputs from the green and blue receptor, would respond most strongly in the green. This is because of the sensitivity curve of the green receptor, which implies that monochromatic yellow light could elicit only a response that is lower than that elicited by green light of equal intensity as the yellow one. Therefore the usual 'yellow preference' of aphids should not be seen as a true colour preference but one that is dependent on the actual intensity of the stimulus.

Similar considerations apply when discussing the response to stimuli perceived as 'red' by human observers. These generally showed a lower attractiveness than green (Table 3). However, there are some interesting exceptions, mainly in the cases where more than one hue or intensity of green was tested (e.g., Burrows et al., 1983). These findings do not require the existence of a red receptor in the tested animals; instead, after examining the spectral reflectance of the stimuli (where published), they can easily be explained by the notion that, in aphids lacking a red receptor, the particular red test stimulus excited the green receptor more than a competing (dark) green test stimulus, while red and green had similar effects on the blue and/ or UV receptor. It could be argued that a lower response of red than green stimuli may be caused by an avoidance behaviour (which would require a red receptor for discrimination between red and green) instead of lower attractiveness. In studies laid out as 
Table 2 Abbreviations used in Table 3

\begin{tabular}{cl}
\hline Abbreviation & Explanation \\
\hline Colours & \\
$\mathrm{g}$ & Green \\
$\mathrm{o}$ & Orange \\
$\mathrm{r}$ & Red \\
$\mathrm{w}$ & White \\
$\mathrm{y}$ & Yellow \\
Sex/morph & \\
$\mathrm{a}$ & Winged autumn migrants (gynoparae) \\
apt & Wingless females \\
$\mathrm{f}$ & Fundatrigeniae \\
$\mathrm{m}$ & Males \\
misc. & Miscellaneous female morphs \\
$\mathrm{s}$ & Winged summer or spring migrants (females) \\
$\mathrm{v}$ & Virginogeniae \\
Stimulus & \\
$\mathrm{b}$ & Broadband stimulus \\
$\mathrm{m}$ & Monochromatic with light intensity controlled \\
(m) & Monochromatic light without controlled light \\
$\mathrm{s}$ & intensity \\
(s) & Spectra shown \\
$\mathrm{N}$ stim. & Peak wavelength given \\
1 & Number of simultaneously presented stimuli \\
2 to n & (=Non-choice tests) \\
Response & Choice tests \\
a & Alighting \\
$\mathrm{f}$ & Flying towards target \\
$\mathrm{p}$ & Probing \\
$\mathrm{w}$ & Walking towards target \\
Environment & \\
$\mathrm{L}$ & Laboratory flight chamber or similar \\
$\mathrm{F}$ & Trap catches in the open field \\
\hline $\mathrm{N}$ & \\
\hline
\end{tabular}

${ }^{a}$ Note that in some studies (References 3, 8, 17, see Table 1) spectra were given only down to about $400 \mathrm{~nm}$, thus not displaying the reflectance in the UV. In such studies, it is uncertain if the reported effects were confounded by UV reflectance

choice experiments, lower attractiveness cannot be separated from avoidance. However, there is one study which provides indirect evidence that avoidance is not involved. Nottingham et al. (1991) studied the behaviour of Rhopalosiphum padi with similar techniques as Hardie (1989) in no-choice experiments and found the usual lower response to red than to green monochromatic light. However, they also found a negative phototaxis to blue monochromatic light which proves that the type of experiment was appropriate to document a negative reaction. In the red, the response was low, but on average, directed towards the target. Thus, avoidance of red light is ruled out here.

Even if a red receptor is absent, red is of course not invisible to insects (Chittka and Waser 1997). Red might be less detectable than green for trichromatic insects, but it depends on the precise form of the reflectance curve, as well as the photoreceptor sensitivities and the opponent mechanism whether a particular red stimulus is actually more or less attractive than a green one (Fig. 3). 'Slight' differences in spectral reflectance of leaves which are regarded as unimportant by other authors (Schaefer and Rolshausen in press) may therefore form a decisive factor for the landing reaction of an aphid on a plant. For example, in Fig. 3 the particular red leaf taken from Sorbus aucuparia would probably be less attractive than the green leaf from the same tree, but for the leaves from Euonymus europaeus, the opposite would be the case. Similarly, different yellow leaves differ substantially in reflectance function (Fig. 2), and this variability is mirrored in the modelled receptor excitations (Fig. 3).

\section{Differences between species and morphs}

Interestingly, not all species seem to show the usual 'yellow preference', at least not to an equal degree. $R$. padi, alternating between grasses (including oats) and its winter host, the tree Prunus padus, showed a preference for green over yellow in a choice experiment, whereas, under the same conditions, Sitobion avenae F., Rhopalosiphum maidis (Fitch) and Schizaphis graminum (Rondani) preferred yellow over green (Kieckhefer et al. 1976). Judging from the transmittance spectra of the filters used by Kieckhefer et al. (1976, Fig. 1), 'yellow' was again associated with a higher intensity than green in these experiments.

In addition to these basic research studies, there have also been agriculturally motivated studies into interspecific differences in the behavioural response to colours. Certain species, including $R$. padi and Sitobion avenae, were found to be under-represented in yellow water traps, compared to suction traps (Eastop 1955; Heathcote 1957; Karl 1991; Boiteau 1990). Because such suction traps do not require an active movement of the animal towards the trap, they can be seen as a non-selective neutral reference, against which catches from traps involving attraction can be compared. Although the species-dependent selectiveness of yellow traps may also be attributed to other factors like trap height (Gonzalez and Rawlins 1968; Karl 1991) or other features of the trap design, interspecific differences in colour preference are also likely to contribute to the observed interspecific variations in trap efficiency (Karl 1991). Further interspecific differences among aphids in the response to different colours have been demonstrated on numerous occasions (e.g., Moericke 1969; A’Brook 1973; Boiteau 1990; Thieme et al. 1994; Hermoso et al. 1998). Interestingly, seasonal differences in the response of aphids to colours were 
Table 3 Behavioural response of aphids to green, yellow, orange, red and white stimuli

\begin{tabular}{|c|c|c|c|c|c|c|c|c|c|c|c|}
\hline \multirow[t]{2}{*}{ Species } & \multirow{2}{*}{$\begin{array}{l}\text { Sex/ } \\
\text { morph }\end{array}$} & \multicolumn{4}{|c|}{ Yellow versus } & \multirow{2}{*}{$\begin{array}{l}\text { Green } \\
\text { versus } \\
\text { red }\end{array}$} & \multicolumn{5}{|l|}{ Methods } \\
\hline & & Green & Orange & Red & $\overline{\text { White }}$ & & Stimulus & $\mathrm{N}$ stim. & Response & Envir. & $\overline{\text { Ref. }}$ \\
\hline \multirow[t]{5}{*}{ Aphids (unidentified sp.) } & $\mathrm{s}$ & $\mathrm{y}$ & $\mathrm{y}$ & $\mathrm{y}$ & $\mathrm{y}$ & $\mathrm{g}$ & $b$ & 15 & a & $\mathrm{F}$ & 12 \\
\hline & $\mathrm{s}$ & $\mathrm{y}$ & - & - & $\mathrm{y}$ & - & $\mathrm{b}$ & 5 & $\mathrm{a}$ & $\mathrm{F}$ & $2 b$ \\
\hline & $\mathrm{a}$ & $\mathrm{y}$ & $\mathrm{y}$ & $\mathrm{y}$ & $\mathrm{y}$ & $(=)$ & $\mathrm{b}$ & 15 & a & $\mathrm{F}$ & 12 \\
\hline & $\mathrm{a}$ & $\mathrm{y}$ & - & - & $\mathrm{y}$ & - & $\mathrm{b}$ & 6 & a & $\mathrm{F}$ & 13 \\
\hline & $\mathrm{a}$ & $\mathrm{y}$ & - & - & $\mathrm{y}$ & - & $\mathrm{b}$ & 3 & a & $\mathrm{F}$ & 4 \\
\hline \multirow[t]{2}{*}{ Aphis sp. } & s? & $\mathrm{y}$ & $\mathrm{y}$ & - & - & - & $\mathrm{b}$ & $3-5$ & a & $\mathrm{L}$ & 10 \\
\hline & $\mathrm{s}$ & $\mathrm{y}$ & - & $\mathrm{y}$ & $\mathrm{y}$ & $\mathrm{g}$ & $\mathrm{b}$ & 12 & $\mathrm{a}$ & $\mathrm{F}$ & 21 \\
\hline A. spiraecola Pagenstecher & $\mathrm{a}$ & $\mathrm{y}$ & - & - & - & - & $\mathrm{b}$ & 3 & a & $\mathrm{F}$ & 7 \\
\hline \multirow[t]{9}{*}{ A. fabae Scopoli } & $\mathrm{f}$ & $=$ & - & $\mathrm{y}$ & - & $\mathrm{g}$ & $(\mathrm{m})(\mathrm{s})$ & 2 & $\mathrm{f}$ & $\mathrm{L}$ & 20 \\
\hline & $\mathrm{s}$ & - & - & - & $\mathrm{y}$ & - & b s & 16 & $\mathrm{a}$ & $\mathrm{F}$ & 15 \\
\hline & $\mathrm{s}$ & $\mathrm{g}$ & $\mathrm{y}$ & $\mathrm{y}$ & - & $\mathrm{g}$ & $\mathrm{m}(\mathrm{s})$ & 1 & $\mathrm{f}$ & $\mathrm{L}$ & 5 \\
\hline & $\mathrm{s}$ & $\mathrm{y}$ & - & - & - & $\mathrm{y}$ & $\mathrm{b}$ & 5 & $\mathrm{a}$ & $\mathrm{F}$ & $14 \mathrm{c}$ \\
\hline & $\mathrm{a}$ & $\mathrm{y}$ & - & $\mathrm{y}$ & - & $\mathrm{g}$ & $(\mathrm{m})(\mathrm{s})$ & 2 & $\mathrm{f}$ & $\mathrm{L}$ & 20 \\
\hline & $\mathrm{a}$ & $\mathrm{y}$ & $\mathrm{y}$ & $\mathrm{y}$ & $\mathrm{y}$ & $\mathrm{g}$ & $\mathrm{b}$ & 18 & $\mathrm{a}$ & $\mathrm{F}$ & 1 \\
\hline & $\mathrm{a}$ & $\mathrm{g}$ & $\mathrm{y}$ & $\mathrm{y}$ & - & $\mathrm{g}$ & $\mathrm{m}(\mathrm{s})$ & 1 & $\mathrm{f}$ & $\mathrm{L}$ & 5 \\
\hline & $\mathrm{v}$ & $=$ & - & $\mathrm{y}$ & - & $\mathrm{g}$ & $(\mathrm{m})(\mathrm{s})$ & 2 & $\mathrm{f}$ & $\mathrm{L}$ & 20 \\
\hline & $\mathrm{m}$ & $\mathrm{g}$ & - & $\mathrm{y}$ & - & $\mathrm{g}$ & $(\mathrm{m})(\mathrm{s})$ & 2 & $\mathrm{f}$ & $\mathrm{L}$ & 20 \\
\hline \multirow[t]{3}{*}{ Brevicoryne brassicae (L.) } & s? & $\mathrm{y}$ & $\mathrm{y}$ & - & - & - & $\mathrm{b}$ & $3-5$ & $\mathrm{a}$ & $\mathrm{L}$ & 10 \\
\hline & $\mathrm{s}$ & $\mathrm{y}$ & - & - & - & - & $\mathrm{b}$ & 3 & $\mathrm{a}$ & $\mathrm{F}$ & $14 b$ \\
\hline & $\mathrm{s}$ & $\mathrm{y}$ & - & - & $\mathrm{y}$ & - & $\mathrm{b}$ & 5 & a & $\mathrm{F}$ & $14 \mathrm{c}$ \\
\hline Capitophorus hippophaes Walker & $\mathrm{s}+\mathrm{a}$ & $\mathrm{y}$ & $\mathrm{y}$ & $\mathrm{y}$ & $\mathrm{y}$ & $\mathrm{g}$ & $\mathrm{b}$ & 18 & $\mathrm{a}$ & $\mathrm{F}$ & 1 \\
\hline C. elaeagni (del Guercio) & $\mathrm{s}$ & $\mathrm{y}$ & - & $\mathrm{y}$ & $\mathrm{y}$ & $\mathrm{g}$ & $\mathrm{b}$ & 12 & $\mathrm{a}$ & $\mathrm{F}$ & 21 \\
\hline Capitophorus spec. & $\mathrm{s}$ & $\mathrm{y}, \mathrm{g} *$ & - & - & - & - & $\mathrm{b}$ & 3 & $\mathrm{a}$ & $\mathrm{F}$ & $14 b$ \\
\hline Cavariella aegopodii (Scopoli) & $\mathrm{s}+\mathrm{a}$ & $\mathrm{y}$ & $\mathrm{y}$ & $\mathrm{y}$ & $\mathrm{y}$ & $\mathrm{g}$ & $\mathrm{b}$ & 18 & $\mathrm{a}$ & $\mathrm{F}$ & 1 \\
\hline Hayhurstia atriplicis $\mathrm{L}$. & $\mathrm{s}$ & $\mathrm{y}$ & - & - & - & - & $\mathrm{b}$ & 3 & a & $\mathrm{F}$ & $14 b$ \\
\hline \multirow[t]{3}{*}{ Hyalopterus pruni (Geoffroy) } & $\mathrm{s}$ & $\mathrm{y}, \mathrm{g}^{*}$ & - & - & - & - & $\mathrm{b}$ & 3 & $\mathrm{a}$ & $\mathrm{F}$ & $14 \mathrm{~b}$ \\
\hline & $\mathrm{s}$ & $\mathrm{y}, \mathrm{g} *$ & - & - & $\mathrm{y}$ & - & $\mathrm{b}$ & 5 & a & $\mathrm{F}$ & $14 \mathrm{c}$ \\
\hline & $\mathrm{s}$ & - & - & - & $\mathrm{y}$ & - & b s & 16 & $\mathrm{a}$ & $\mathrm{F}$ & 15 \\
\hline Hyperomyzus spec. & $\mathrm{a}$ & $\mathrm{y}$ & $\mathrm{y}$ & $\mathrm{y}$ & - & $\mathrm{g}$ & $\mathrm{b}$ & 15 & a & $\mathrm{F}$ & 12 \\
\hline Lipaphis erysimi Kalt. & $?$ & $\mathrm{y}$ & - & $\mathrm{y}$ & $\mathrm{y}$ & $\mathrm{g}$ & $\mathrm{b}$ & 4 & $\mathrm{a}$ & $\mathrm{F}$ & 19 \\
\hline \multirow[t]{3}{*}{ Macrosiphum euphorbiae (Thomas) } & $\mathrm{s}$ & $\mathrm{y}, \mathrm{g} *$ & $\mathrm{o}$ & $\mathrm{y}, \mathrm{r}^{*}$ & $\mathrm{y}$ & $\mathrm{r}, \mathrm{g}^{*}$ & b s & 1 & $\mathrm{p}$ & $\mathrm{L}$ & 17 \\
\hline & $?$ & $\mathrm{y}$ & - & - & - & - & $\mathrm{b}$ & 1 & a & $\mathrm{L}$ & $2 \mathrm{a}$ \\
\hline & apt & $\mathrm{y}$ & $\mathrm{y}$ & $\mathrm{y}$ & $\mathrm{y}$ & $\mathrm{r}, \mathrm{g}^{*}$ & b s & 4 & $\mathrm{w}$ & $\mathrm{L}$ & 3 \\
\hline \multirow[t]{9}{*}{ Myzus persicae (Sulzer) } & $\mathrm{s}$ & $\mathrm{y}$ & - & $\mathrm{y}$ & $\mathrm{y}$ & $\mathrm{g}$ & $\mathrm{b} ?$ & 2 & $\mathrm{a}$ & $\mathrm{L}$ & 18 \\
\hline & $\mathrm{s}$ & $\mathrm{y}, \mathrm{g} *$ & o & $\mathrm{y}$ & $\mathrm{y}$ & $\mathrm{r}, \mathrm{g}^{*}$ & b s & 1 & $\mathrm{p}$ & $\mathrm{L}$ & 17 \\
\hline & $\mathrm{s}$ & $\mathrm{y}$ & - & - & - & - & $\mathrm{b}$ & 3 & a & $\mathrm{F}$ & $14 a, b$ \\
\hline & $\mathrm{s}$ & $\mathrm{y}$ & - & - & $\mathrm{y}$ & - & $\mathrm{b}$ & 5 & $\mathrm{a}$ & $\mathrm{F}$ & $14 \mathrm{c}$ \\
\hline & $\mathrm{s}$ & $\mathrm{y}$ & - & $\mathrm{y}$ & $\mathrm{y}$ & $\mathrm{g}$ & $\mathrm{b}$ & 12 & $\mathrm{a}$ & $\mathrm{F}$ & 21 \\
\hline & s? & $\mathrm{y}$ & $\mathrm{y}$ & - & - & - & $\mathrm{b}$ & $3-5$ & $\mathrm{a}$ & $\mathrm{L}$ & 10 \\
\hline & misc. & $\mathrm{y}, \mathrm{g} *$ & $\mathrm{y}, \mathrm{o}^{*}$ & $\mathrm{y}$ & $\mathrm{y}$ & $\mathrm{g}$ & $\mathrm{m}(\mathrm{s})$ & 1 & $\mathrm{p}$ & $\mathrm{L}$ & 11 \\
\hline & apt & $\mathrm{g}$ & - & $\mathrm{y}$ & - & $\mathrm{g}$ & b s & $1,2 ?$ & $\mathrm{w}$ & $\mathrm{L}$ & 8 \\
\hline & $?$ & $\mathrm{y}$ & - & - & - & - & $\mathrm{b}$ & 1 & $\mathrm{a}$ & $\mathrm{L}$ & $2 \mathrm{a}$ \\
\hline \multirow[t]{3}{*}{ Phorodon humuli (Schrank) } & $\dot{s}$ & $\mathrm{y}$ & - & - & - & - & $\mathrm{b}$ & 3 & $\mathrm{a}$ & $\mathrm{F}$ & 4 \\
\hline & $\mathrm{a}$ & $\mathrm{y}, \mathrm{g} *$ & $\mathrm{y}$ & $\mathrm{y}$ & $\mathrm{y}$ & $\mathrm{g}$ & $\mathrm{b}$ & 9 & a & $\mathrm{F}$ & 6 \\
\hline & $\mathrm{m}$ & $\mathrm{y}$ & $\mathrm{y}$ & $\mathrm{y}$ & $\mathrm{y}$ & $\mathrm{g}$ & $\mathrm{b}$ & 9 & $\mathrm{a}$ & $\mathrm{F}$ & 6 \\
\hline Rhopalosiphum maidis (Fitch) & $\mathrm{s}$ & $\mathrm{y}$ & - & $\mathrm{y}$ & - & $\begin{array}{l}\mathrm{s} \\
\mathrm{g}\end{array}$ & b s & 4 & w? & $\mathrm{L}$ & 9 \\
\hline \multirow[t]{2}{*}{ R. oxyacanthae (Schrank) } & $\mathrm{s}+\mathrm{a}$ & $\mathrm{y}$ & $\mathrm{y}$ & $\mathrm{y}$ & $\mathrm{y}$ & $\mathrm{r}, \mathrm{g} *$ & $\mathrm{~b}$ & 18 & $\mathrm{a}$ & $\mathrm{F}$ & 1 \\
\hline & $\mathrm{m}$ & 0 & 0 & 0 & w & 0 & $\mathrm{~b}$ & 18 & a & $\mathrm{F}$ & 1 \\
\hline \multirow[t]{4}{*}{ R. padi L. } & $\mathrm{s}$ & $\mathrm{g}$ & - & $\mathrm{y}$ & - & $\mathrm{g}$ & b s & 4 & w? & $\mathrm{L}$ & 9 \\
\hline & $\mathrm{s}$ & $\mathrm{g}$ & $\mathrm{y}$ & $\mathrm{y}$ & - & $\mathrm{g}$ & $\mathrm{m}(\mathrm{s})$ & 1 & f & $\mathrm{L}$ & 16 \\
\hline & $\mathrm{s}+\mathrm{a}$ & $\mathrm{y}$ & $\mathrm{y}$ & $\mathrm{y}$ & $\mathrm{y}$ & $\mathrm{r}, \mathrm{g} *$ & b & 18 & $\mathrm{a}$ & $\mathrm{F}$ & 1 \\
\hline & $\mathrm{a}$ & $\mathrm{y}$ & $\mathrm{y}$ & $\mathrm{y}$ & $\mathrm{y}$ & $\mathrm{r}, \mathrm{g}^{*}$ & $\mathrm{~b}$ & 9 & $\mathrm{a}$ & $\mathrm{F}$ & 6 \\
\hline Schizaphis graminum (Rondani) & $\mathrm{m}$ & $\mathrm{y}$ & $\mathrm{y}$ & $\mathrm{y}$ & $\mathrm{y}$ & $\mathrm{g}$ & $\mathrm{b}$ & 18 & a & $\mathrm{F}$ & 1 \\
\hline & $\mathrm{m}$ & $\mathrm{y}$ & $\mathrm{y}$ & $\mathrm{y}$ & $\mathrm{y}$ & $\mathrm{r}, \mathrm{g}^{*}$ & $\mathrm{~b}$ & 9 & $\mathrm{a}$ & $\mathrm{F}$ & 6 \\
\hline & $\mathrm{s}$ & $\mathrm{y}$ & - & $\mathrm{y}$ & - & $\mathrm{g}$ & b s & 4 & w? & $\mathrm{L}$ & 9 \\
\hline
\end{tabular}


Table 3 continued

\begin{tabular}{|c|c|c|c|c|c|c|c|c|c|c|c|}
\hline \multirow[t]{2}{*}{ Species } & \multirow{2}{*}{$\begin{array}{l}\text { Sex/ } \\
\text { morph }\end{array}$} & \multicolumn{4}{|c|}{ Yellow versus } & \multirow{2}{*}{$\begin{array}{l}\text { Green } \\
\text { versus } \\
\text { red }\end{array}$} & \multicolumn{5}{|l|}{ Methods } \\
\hline & & Green & Orange & Red & White & & Stimulus & $\mathrm{N}$ stim. & Response & Envir. & Ref. \\
\hline \multirow[t]{2}{*}{ Sitobion avenae (Fab.) } & $\mathrm{s}$ & $\mathrm{y}$ & - & $\mathrm{y}$ & - & $\mathrm{g}$ & b s & 4 & w? & $\mathrm{L}$ & 9 \\
\hline & $\mathrm{s}+\mathrm{a}$ & $\mathrm{y}, \mathrm{g}^{*}$ & $\mathrm{y}$ & $\mathrm{r}$ & $\mathrm{y}$ & $\mathrm{r}, \mathrm{g}^{*}$ & $\mathrm{~b}$ & 18 & $\mathrm{a}$ & $\mathrm{F}$ & 1 \\
\hline \multirow[t]{2}{*}{ S. fragariae (Walker) } & $\mathrm{a}$ & $\mathrm{y}, \mathrm{g} *$ & $\mathrm{y}, \mathrm{o}^{*}$ & $\mathrm{y}, \mathrm{r}^{*}$ & $\mathrm{y}, \mathrm{w}^{*}$ & $\mathrm{r}, \mathrm{g}^{*}$ & $\mathrm{~b}$ & 9 & $\mathrm{a}$ & $\mathrm{F}$ & 6 \\
\hline & $\mathrm{m}$ & $\mathrm{y}, \mathrm{g} *$ & $\mathrm{o}$ & $\mathrm{y}$ & $\mathrm{y}$ & $\mathrm{g}$ & $\mathrm{b}$ & 9 & $\mathrm{a}$ & $\mathrm{F}$ & 6 \\
\hline
\end{tabular}

Abbreviations and references see Tables 1 and 2. In the cells, a ' $y$ ' means that yellow was preferred over the colour denoted in that column etc. -: not tested, =: equal numbers, 0 : no individuals caught

*Several colours were tested and the direction of the aphid's preference depended on the particular colours used

also reported, with significant interactions between colour and month in Aphis fabae and Rhopalosiphum padi, but not in Sitobion avenae and Cavariella aegopodii Scopoli (A’Brook 1973). Moericke (1955a, b) observed that the attractiveness of green relative to yellow was lower in autumn than in spring and summer, but it was not clear if that effect was due to different species composition or intraspecific alterations of flight behaviour. Prasad and Lal (2001) report weekly catches of Lipaphis erysimi Kaltenbach in green, white, yellow and red traps over 18 weeks in 3 years, but seasonal differences in the response to the colours do not seem to be consistent.

From the sensory point of view, the causes for the differences in behaviour of certain aphid species are yet unclear. It is not necessary to postulate an additional red receptor to explain a green preference over yellow. This preference could instead be caused by a different evaluation of the output from a colour opponent coding system of type described by Eq. 3, in that the maximum behavioural response is not linked to the maximum excitation of the opponent mechanism but to some intermediate value-for example, the most attractive stimulus could be one that excites the green receptor twice as much as the blue receptor-but not four times as much (as a yellow stimulus might).

\section{Response to colour contrasts}

In the process of host finding, visual signals from a plant are never isolated, because the plant is always surrounded by a visual background. Apart from the direct optical influence of the plant on the aphid described in the previous sections, a secondary effect of the background on landing is likely, such as a colour contrast or brightness contrast. Moericke (1955b) found that a white cloth around a suction trap that was level with the soil, reduced aphid catches to $4-24 \%$ of the catch when the surrounding was uncovered, i.e. with a soil background. Later, Kring (1964) made similar observations with yellow traps surrounded by aluminium foil.

In the following years, a great number of studies showed that mulches, i.e. different materials applied to cover the soil around crop plants, reduce the number of alighting aphids, and are able to reduce the incidence of aphid-transmitted virus diseases. The materials applied included aluminium, and white, black or differently coloured (blue, green, silver, and gold) plastic mulch (Dickson and Laird 1966; Adlerz and Everett 1968; Heathcote 1968; Kring 1970; Daiber and Donaldson 1976; Eulitz 1977; Wyman et al. 1979; Liburd et al. 1998; Yoltas et al. 2001; and references in Döring et al. 2004).

Interestingly, nearly all colours or materials tested show some degree of reduction in the number of alate aphids caught in traps in the mulched vs. in un-mulched treatments. The highest efficiency was consistently found with aluminium, often reducing winged aphids that landed in traps by over $90 \%$. In line with this result, it was found that aluminium mulch reduced the incidence of aphid-vectored plant viruses in various crops to a high degree. Black mulch material also lead to decreased aphid infestation on the crop, aphid landing rates or virus incidence, but usually with a lower reduction efficiency and with a high variability of the efficiency between the studies (e.g., Johnson et al. 1967; Jones and Chapman 1968; Brust 2000).

None of these studies, however, presented full reflectance spectra of the mulches or separated light intensity and colour. In an attempt to contribute to a better understanding of the mechanisms underlying the effects of mulches, Döring et al. (2004) compared 16 spectrally characterised backgrounds regarding their effect on aphids landing in green water traps. A negative correlation between UV reflectance of the background and the aphid catch in the traps was found for the most common species encountered. However, the effects of UV and blue reflectance could not be 
separated because they had not been varied independently.

Green living plants as background of targets for landing, such as used in intercropping systems, are also efficient in reducing aphid catches (e.g. Moericke 1957; Müller 1964; González and Rawlins 1968; Heathcote 1968; Smith 1976; Bigler et al. 1995; Lehmhus 2001). For green mulches, colour contrast effects are conceivable but have not been separated experimentally from other effects. Other confounding factors, like enhanced conditions for aphid predators, render a statement on green living mulches regarding visual orientation very difficult.

\section{Ecological implications: adaptation to host leaf colours?}

Concerning the ecological implications of the responses of aphids to coloured stimuli, three different questions have been raised, which are related to adaptive responses to green, yellow and red foliage. In terms of green leaves, the question is whether there is a specific adaptation of aphid visual system to optimise the spectral discrimination between their (green-leafed summer) hosts and non-host plants, or put slightly differently, if host plants can be discriminated from non-hosts by their colour. Prokopy and Owens (1983, p. 357) conjectured that "with few exceptions ... it is unlikely that plant spectral quality constitutes a hostplant specific character for herbivorous insects because of its similarity among most plants'; see also Kennedy et al. (1961). However, from an evolutionary viewpoint, the mentioned dissimilarities between different aphid species in their response to coloured stimuli might be explicable by assuming adaptation of their visual preferences to a specific task, possibly host finding. For example, Moericke (1969) compared the response of winged Aphis fabae and Hyalopterus pruni (Geoffroy) to coloured stimuli of different saturation and to their respective host plants. $H$. pruni was attracted to the unsaturated stimuli while $A$. fabae preferred the saturated ones. Because Moericke (1969) characterised the common reed (Phragmites australis (Cav.) Trin. ex Steud.), the secondary host plant of $H$. pruni, as displaying a less saturated green than hosts of A. fabae, he concluded that between species-variation in responses to colours may be adaptive in this case.

What could be the adaptive significance of the 'yellow preference' of many aphids? Because young (yellowish) leaf tissue as well as autumnal yellow leaves tend to have a higher flow of aphid accessible nitrogen sources in the phloem, this was seen as a point for explaining ultimate causes of yellow preference in certain aphids by some authors (Kennedy et al. 1961; Dixon 1985). Total leaf nitrogen levels on the other hand, tend to be associated with lower overall reflectance in the insect visible spectrum (Judkins and Wander 1950; Serrano et al. 2000). In most, but not all deciduous trees, nutrients are translocated from the leaves in autumn (Dixon 1971; Holopainen and Peltonen 2002), leading to a high flux of aphid-accessible nitrogen in the phloem. The sharp decrease of leaf nitrogen content linked to this nutrient translocation was shown by Tamm (1951) in the birch tree Betula. In the related genus Alnus, on the other hand, which lives in a symbiosis with $\mathrm{N}$-fixing actinomycetes, no such translocation takes place and autumn leaves are shed when still green. Therefore, it would be interesting to compare autumn migrants of aphid species colonizing Betula trees with those colonizing Alnus, regarding both their physiological and behavioural responses to coloured stimuli.

However, it might well be that yellow preference of some aphid species and morphs is non-adaptive and that yellow just represents a 'supernormal foliage stimulus' for the herbivorous insects (Prokopy and Owens 1983). The proximate perspective on this interpretation is the mechanistic explanation given above-that if green-ness of leaves is assessed by an opponent mechanism described in Eq. 3, yellow leaves might stimulate such a mechanism even stronger than green leaves. Even though this mechanism is slightly sub-optimal (because it might occasionally guide aphids to yellow flowers rather than leaves, for example), it might not be selected against because of the overwhelming dominance of green leaf area in most temperate habitats.

The third question, regarding red leaves, was prompted by the recent debate on autumn leaf colouration. As shown above, insects without red receptors cannot strictly (i.e. independently of intensity) distinguish red or orange or yellow from green (e.g. Chittka and Waser 1997). Red leaves are therefore not necessarily discernable from green leaves for aphids equipped with the colour opponent mechanism described in Eq. 3. In other words, in the perception of aphids, red leaves may not form a group that would be distinctive from green leaves by colour, but only by intensity. Since, however, light intensity is highly variable in natural habitats (e.g. Lythgoe 1979), light intensity alone might not be a reliable indicator for any host-associated parameter of relevance to an aphid. Even if, in a given tree species, reflectance from red autumn leaves was consistently lower (or higher) than from green leaves, noise from small-scale illumination 
variability would severely diminish the indicator value of 'red'. Hamilton and Brown (2001, p. 1492) predicted that 'specialist aphids of red autumnal trees will have red-sensitive vision and show increasing aversion to increasing red coloration'. However, so far there is no evidence for red receptors in aphids (see previous sections).

In any case, it is evident from the above that spectral measurements of leaves as well as physiological characterisation of spectral sensitivities of the species in question are necessary before any sensible speculation on host-herbivore co-evolution can be made. It is also risky to extrapolate from our knowledge on the generalist species Myzus persicae and Aphis fabae to the many specialist aphids that have narrow affinities to certain plant hosts. For these specialists, we urgently need data on spectral sensitivities, as well as rigorous quantifications of behavioural responses to coloured stimuli under controlled laboratory conditions.

\section{Agricultural implications: optimisation of aphid monitoring and aphid control}

Our knowledge of aphid responses to colours is relevant for the following four approaches (also see Prokopy and Owens 1983, p. 356). First, leaf colouration of crop plants may be altered by breeding, possibly leading to disrupted host finding by aphids. This includes both the selection for red or brownish leaf colours and for pubescence hairs. First steps in this direction have already been made by Müller (1964), reporting on aphid infestation on salad, and are currently under way in potatoes (B. Gerowitt pers. comm.).

The second approach is the optimisation of traps for aphid monitoring (Thieme et al. 1994). A better understanding of the species-specific colour preference in aphids will possibly allow designing traps that are better adapted to a particular host-aphid combination.

The third strategy affected by the knowledge on aphid colour responses is the use of reflective mulches, although non-visual factors may also play a role in the effects observed (Döring et al. 2004). In the investigations on the use of mulch for protection of plants from virus diseases, three features were often stated: (1) The higher the percentage of soil covered with mulch the higher the efficiency (e.g., Adlerz and Everett 1968; Lehmhus 2001); (2) The efficiency of the mulch decreases over the growing season along with the increasing canopy of the plant (e.g., Brust 2000); (3) The comparably high costs of mulching are only economically justified in high value crops or when se- vere losses occur regularly due to virus diseases (e.g., Brust 2000). Finally, there is a recent report on the use of UV absorbing fabric (netting and plastics) in greenhouses for aphid control (Kumar and Poehling 2006). Under UV-blocked conditions, fewer aphids (Aphis gossypii Glover) entered the greenhouse compared with the ones having higher UV intensity. Also, significantly fewer alate aphids per leaf were counted in the greenhouses with low UV intensity. As the precise mechanisms for these relatively strong effects are not clear yet, this approach deserves closer investigation, especially regarding the visually guided behaviour of the affected pests.

\section{Conclusions}

It is clear from the reported studies that any generalisation concerning aphid colour preferences from one species to another has to be treated with caution. Particularly, ecological theories on aphid-host-co-evolution need to be based on solid data on object spectral reflectance and receiver spectral sensitivity. Therefore, we hope that progress will be made in the physiological and behavioural domain to obtain a better basis for the understanding of more species of aphids' responses to colours. This will certainly generate clarification in the field of sensory ecology, but also in agricultural entomology and pest control.

Acknowledgements During the writing of this article, TFD was supported by a fellowship within the Postdoc-Programme of the German Science Foundation (Deutsche Forschungsgemeinschaft, DFG).

\section{References}

A'Brook J (1973) Observations on different methods of aphid trapping. Ann Appl Biol 74:263-277

Adlerz WC, Everett PH (1968) Aluminum foil and white polyethylene mulches to repel aphids and control watermelon mosaic. J Econ Entomol 61:1276-1279

Archetti M, Leather SR (2005) A test of the coevolution theory of autumn colours: colour preference of Rhopalosiphum padi on Prunus padus. Oikos 110:339-343

Arikawa K, Inokuma K, Eguchi E (1987) Pentachromatic visual system in a butterfly. Naturwissenschaften 74:297-298

Auclair JL (1967) Effects of light and sugars on rearing the cotton aphid, Aphis gossypii, on a germ-free and holidic diet. J Insect Physiol 13:1247-1268

Baldy C, Rabasse J-M (1983) Caractéristiques spectrales de pièges jaunes utilisés pour la capture des aphides. Agronomie 3:161-166

Bauer-Dubau K, Scheurer S (1993) First reports of honey-dewproducing aphids (Aphidina: (Lachnidae)) on conifers, their prefered locations and abundance during 1992 in "Botanischer Garten Berlin". Mitteilungen der Deutschen 
Gesellschaft für Allgemeine und Angewandte Entomologie (Germany) 9:715-719

Bigler F, Waldburger M, Frei G (1995) Vier Maisanbauverfahren 1990-1993-Krankheiten und Schädlinge. Agrarforschung 2(9):380-382

Boiteau G (1990) Effect of trap color and size on relative efficiency of water-pan traps for sampling alate aphids (Homoptera: Aphididae) on potato. J Econ Entomol 83:937-942

Briscoe A, Chittka L (2001) Evolution of color vision in insects. Annu Rev Entomol 46:471-510

Broadbent L (1949) Factors affecting the activity of alatae of the aphids Myzus persicae (Sulzer) and Brevicoryne brassicae (L.). Ann Appl Biol 36:40-62

Brown MW, Gleen DM, Wisiniewski ME (1991) Functional and anatomical disruption of apple roots by the woolly apple aphid (Homoptera : Aphididae). J Econ Entomol 84:1823-1826

Brust GE (2000) Reflective and black mulch increase yield in pumpkins under virus disease pressure. J Econ Entomol 93:828-833

Budnik K, Laing MD, da Graça JV (1996) Reduction of yield losses in pepper crops caused by Potato Virus $\mathrm{Y}$ in KwaZulu-Natal, South Africa, using plastic mulch and yellow sticky traps. Phytoparasitica 24:119-124

Burrows PM, Barnett OW, Zimmerman MT (1983) Color attraction and perception in Macrosiphon euphorbae. Can J Zool 61:202-210

Campbell CAM (1991) Response of Phorodon humuli to yellow and green hop foliar colours. Entomol Exp Appl 60:95-99

Chapman RF, Bernays EA, Simpson SJ (1981) Attraction and repulsion of the aphid, Cavariella aegopodii by plant odours. J Chem Ecol 7:881-888

Chittka L (1996a) Does bee colour vision predate the evolution of flower colour? Naturwissenschaften 83:136-138

Chittka L (1996b) Optimal sets of color receptors and opponent process for coding of natural objects in insect vision. $\mathbf{J}$ Theoret Biol 181:179-196

Chittka L, Waser NM (1997) Why red flowers are not invisible for bees. Israelian J Plant Sci 45:69-183

Chittka L, Wells H (2004) Color vision in bees: mechanisms, ecology and evolution. In: Prete F (ed) How simple nervous systems create complex perceptual worlds. MIT Press, Boston, pp 165-191

Chittka L, Beier W, Hertel H, Steinmann E, Menzel R (1992) Opponent colour coding is a universal strategy to evaluate the photoreceptor inputs in hymentoptera. J Compar Physiol A 170:545-563

Daiber CC, Donaldson JMI (1976) Watermelon mosaic virus in vegetable marrows: the effect of aluminium foil on the vector. Phytophylactica 8:85-86

Dartnall HJA, Bowmaker JK, Mollon JD (1983) Human visual pigments: microspectrophotometric results from eyes of seven persons. Proc Royal Soc Lond B 220:115-130

Dickson RC, Laird RF (1966) Aluminum foil to protect melons from watermelon mosaic virus. Plant Disease Rep 50:305

Dilawari VK, Atwal AS (1989) Response of mustard aphid Lipaphis erysimi (Kalt.) to allylisothiocyanate. J Insect Sci 2:103-108

Dixon AFG (1971) The life cycle and host preferences of the bird cherry-oat aphid, Rhopalosiphum padi L., and their bearing on the theories of host alternation in aphids. Ann Appl Biol 68:135-147

Dixon AFG (1985) Aphid ecology. Blackie, Glasgow 157 pp

Dominy NJ, Lucas PW, Ramsden LW, Riba-Hernandez P, Stoner KE, Turner IM (2002) Why are young leaves red? Oikos 98:163-176
Döring TF, Skorupski P (2007) Host and non-host leaves in the colour space of the colorado potato beetle (Coleoptera: Chrysomelidae). Entomol Gen (in press)

Döring TF, Kirchner SM, Kühne S, Saucke H (2004) Response of alate aphids to green targets on differently coloured backgrounds. Entomol Exp Appl 113:53-62

Dyer A, Neumeyer C (2005) Simultaneous and successive colour discrimination in the honeybee (Apis mellifera). J Compar Physiol A 191:547-557

Eastop VF (1955) Selection of aphid species by different kinds of insect traps. Nature 176:936

Eulitz EG (1977) Aluminium foil for the control of watermelon mosaic in vegetable marrow. Phytophylactica 9:23-23

Fokkema NJ, Riphagen I, Poot RJ, de Jong C (1983) Aphid honeydew, a potential stimulant of Cochliobolus sativus and Septoria nodorum and the competitive role of saprophytic mycoflora. Trans Brit Mycol Soc 81:355-363

Goldsmith TH (1991) The evolution of visual pigments and colour vision. In: Gouras P (ed) Vision and visual dysfunction. Macmillan, Houndsmills, UK, pp 62-89

Goldsmith TH (1994) Ultraviolet receptors and color vision: evolutionary implications and a dissonance of paradigms. Vision Res 34:1479-1487

Gonzalez D, Rawlins WA (1968) Aphid sampling efficiency of Möericke Traps affected by height and background. J Econ Entomol 61:109-114

Hamilton WD, Brown SP (2001) Autumn tree colours as a handicap signal. Proc Roy Soc B 268:1489-1493

Hardie J (1989) Spectral sensitivity for targeted flight in the black bean aphid, Aphis fabae. J Insect Physiol 35:619-626

Hardie J, Nunes MV (2001) Aphid photoperiodic clocks. J Insect Physiol 47:821-832

Hardie J, Isaacs R, Pickett JA, Wadhams LJ, Woodcock CM (1994) Methyl salicylate and (-)-(1R,5S)-myrtenal are plantderived repellents for black bean aphid, Aphis fabae Scop. (Homoptera: Aphididae). J Chem Ecol 20:2847-2855

Hardie J, Storer JR, Cook FJ, Campbell CAM, Wadhams LJ, Lilley $R$, Peace L (1996) Sex pheromone and visual trap interactions in mate location strategies and aggregation by host alternatingaphids in the field. Physiol Entomol 21:97-106

Heathcote GD (1957) The comparison of yellow cylindrical, flat and water traps, and of Johnson suction traps, for sampling aphids. Ann Appl Biol 45:133-139

Heathcote GD (1968) Protection of sugar beet stecklings against aphids and viruses by cover crops and aluminum foil. Plant Pathol 17:158-161

Hennig E (1963) Zum Probieren oder sogenannten Probesaugen der Schwarzen Bohnenlaus (Aphis fabae Scop.). Entomol Exp Appl 6:326-336

Hermoso A, Pérez E, Carbonell EA, Real V (1998) Comparación de sistemas de captura de áfidos (Homoptera, Aphidinea) en cítricos. Investigación Agraria: Producción y Protección Vegetal 13:121-128

Hodgson CJ, Elbakiet IB (1985) Effect of colour and shape of 'target' hosts on the orientation of emigrating adult apterous Myzus persicae in the laboratory. Entomol Exp Appl 38:267-272

Holopainen JK, Peltonen P (2002) Bright autumn colours of deciduous trees attract aphids: nutrient retranslocation hypothesis. Oikos 99:184-188

Johnson B (1958) Factors affecting the locomotor and settling responses of aphids. Animal Behav 6:9-26

Johnson GV, Bing A, Smith FF (1967) Reflective surfaces used to repel dispersing aphids and reduce spread ot aphid-borne cucumber mosaic virus in gladiolus plantings. J Econ Entomol 60:16-19 
Jones FR, Chapman RK (1968) Aluminium foil and other reflective surfaces to manipulate the movement of aphid vectors of plant viruses. Proc Entomol Soc Am, North Central Branch 23:146-148

Judkins WP, Wander IW (1950) Correlation between leaf colour, leaf nitrogen content, and growth of apple, peach and grape plants. Plant Physiol 25:78-85

Karl E (1991) Einsatz einer Saugfalle zur Überwachung der Flugaktivität von Getreideblattläusen (Homoptera Aphidinea: Aphididae). Entomol Gen 16:161-166

Kennedy JS (1950) Aphid migration and the spread of plant viruses. Nature 165:1024-1025

Kennedy JS (1966) The balance between antagonistic induction and depression of flight activity in Aphis fabae Scopoli. J Exp Biol 45:215-228

Kennedy JS, Booth CO, Kershaw WJS (1959a) Host finding by aphids in the field-I. Gynoparae of Myzus persicae (Sulzer). Ann Appl Biol 47:410-423

Kennedy JS, Booth CO, Kershaw WJS (1959b) Host finding by aphids in the field-II. Aphis fabae Scop. (Gynoparae) and Brevicoryne brassicae L.; with a re-appraisal of the role of host-finding behaviour in virus spread. Ann Appl Biol 17:424-444

Kennedy JS, Booth CO, Kershaw WJS (1961) Host finding by aphids in the field-III. Visual attraction. Ann Appl Biol 49:1-21

Kieckhefer RW, Dickman DA, Miller EL (1976) Color responses of cereal aphids. Ann Entomol Soc Am 69:721-724

Kirchner SM, Döring TF, Saucke H (2005) Evidence for trichromacy in the green peach aphid Myzus persicae (Homoptera: Aphididae). J Insect Physiol 51:1266-1260

Kring JB (1964) New ways to repel aphids. Front Plant Sci 17:6-7

Kring JB (1967) Alighting of aphids on colored cards in a flight chamber. J Econ Entomol 60:1207-1210

Kring JB (1970) Determining the number of aphids over reflective surfaces. J Econ Entomol 63:1350-1353

Kring JB (1972) Flight behaviour of aphids. Annu Rev Entomol 17:461-492

Kumar P, Poehling H-M (2006) UV-blocking plastic films and nets influence vectors and virus transmission on greenhouse tomatoes in the humid tropics. Environ Entomol 35:1069-1082

Lehmhus J (2001) Auswirkungen von Untersaaten in Weißkohlkulturen auf Populationsdynamik der Schadinsekten, die Unkräuter und den Ertrag. PhD-Thesis, University of Hannover, Germany

Liburd OE, Casagrande RA, Alm SR (1998) Evaluation of various color hydromulches and weed fabric on broccoli insect populations. J Econ Entomol 91:256-262

Lin J-T, Hwang P-C, Tung L-C (2002) Visual organization and spectral sensitivity of larval eyes in the moth Trabala vishnou Lefebur (Lepidoptera: Lasiocampidae). Zool Stud 41:366-375

Lythgoe JN (1979) The ecology of vision. Clarendon Press, Oxford, $244 \mathrm{pp}$

Manetas Y (2006) Why some leaves are anthocyanic and why most anthocyanic leaves are red? Flora 201:163-177

Menzel R (1979) Spectral sensitivity and color vision in invertebrates. In: Autrum $\mathrm{H}$ (ed) Comparative physiology and evolution of vision in invertebrates-A: Invertebrate photoreceptors. handbook of sensory physiology, vol VII/6A. Springer-Verlag, Berlin, pp 504-580

Menzel R, Backhaus W (1991) Color vision in insects. In: Gouras $P$ (ed) Vision and visual dysfunction, vol. VI. The perception of colour. MacMillan Press, Houndsmills, pp 262-293

Merzlyak MN, Gitelson AA, Chivkunova OB, Raitkin VYu (1999) Non-destructive optical detection of pigment changes during leaf senescence and fruit ripening. Physiol Plantarum 106:135-141

Miles PW (1989) Specific responses and damage caused by Aphidoidea. In: Minks AK, Harrewijn P (eds) Aphids - their biology, natural enemies and control. Elsevier, Amsterdam, pp 23-47

Moericke V (1941) Zur Lebensweise der Pfirsichlaus (Myzodes persicae Sulz.) auf der Kartoffel. Inaugural-Disseration Universität Bonn, $101 \mathrm{pp}$

Moericke V (1950) Über das Farbsehen der Pfirsichblattlaus (Myzodes persicae Sulz.). Z Tierpsychol 7:263-274

Moericke V (1951) Eine Farbfalle zur Kontrolle des Fluges von Blattläusen, insbesondere der Pfirsichblattlaus, Myzodes persicae (Sulz.). Nachrichtenblatt des Deutschen Pflanzenschutzdientes 3:23-24

Moericke V (1952) Farben als Landereize für geflügelte Blattläuse (Aphidoidea). Z Naturforschorschung 7b:304-309

Moericke V (1953) Wie finden geflügelte Blattläuse ihre Wirtspflanze? Mitteilungen der Biologischen Zentralanstalt, Berlin Dahlem 75:90-97

Moericke V (1955a) Über die Lebensgewohnheiten der geflügelten Blattläuse (Aphidina) unter besonderer Berücksichtigung des Verhaltens beim Landen. Z Ange Entomol 37:29-91

Moericke V (1955b) Über das Verhalten phytophager Insekten während des Befallsfluges unter dem Einfluß von weißen Flächen. Z Pflanzenkrankh Pflanzensch 62:588-593

Moericke V (1957) Der Flug von Insekten über pflanzenfreien und pflanzenbewachsenen Flächen. Z Pflanzenkrankh Pflanzensch 64:507-514

Moericke V (1969) Hostplant specific colour behaviour by Hyalopterus pruni (Aphididae). Entomol Exp Appl 12:524-534

Moericke V (1979) Nachweis des Farbensehens bei Blattläusen. Publikationen zu Wissenschaftlichen Filmen - Sektion Biologie, Serie 12 (1), Film C (1278) Institut für Wissenschaftlichen Film, Göttingen, 17 pp

Moore JB (1937) Reactions of aphids to colored insecticides. J Econ Entomol 30:305-309

Müller HJ (1964) Über die Anflugdichte von Aphiden auf farbige Salatpflanzen. Entomol Exp Appl 7:85-104

Neumeyer C (1981) Chromatic adaptation in the honeybee: Successive color contrast and color constancy. J Compar Physiol A 144:543-553

Nottingham S, Hardie J, Tatchell GM (1991) Flight behaviour of the bird cherry aphid, Rhopalosiphum padi. Physiol Entomol 16:223-229

Park KC, Elias D, Donato B, Hardie J (2000) Electroantennogram and behavioural responses of different forms of the bird cherry-oat aphid, Rhopalosiphum padi, to sex pheromone and a plant volatile. J Insect Physiol 46:597-604

Pelletier Y (1990) The role of the color of the subtratum on the initiation of the probing behavior in Myzus persicae (Sulzer) and Macrosiphum euphorbiae (Thomas) (Homoptera: Aphididae). Can J Zool 68:694-698

Petterson J (1970) Studies on Rhapalosiphum padi (L.) I. Laboratory studies on olfactometric responses to the winter host Prunus padus L. Lantbrukshögskolans Annaler 36:381-399

Pospíšil J (1963) Orientation of Myzodes persicae (Sulz.) to light. Acta Soc Entomol Čechosloveniae 60:94-98

Powell G, Hardie J, Pickett JA (1995) Response of Myzus persicae to the repellent polygodial in choice and no-choice video assays with young and mature leaf tissure. Entomol Exp Appl 74:91-94

Prasad SK, Lal J (2001) Population dynamics of alate mustard aphid, Lipaphis erysimi, and its colour preference. Indian J Entomol 63:285-289 
Prokopy RJ, Owens ED (1983) Visual detection of plants by herbivorous insects. Annu Rev Entomol 28:337-364

Rabbinge R, Drees EM, van der Graaf M, Verberne FCM, Wesselo A (1981) Damage effects of cereal aphids in wheat. Netherlands J P1ant Pathol 87:217-232

Rieckmann W, Zahn V (1998) Relationship of aphid flight behaviour and successful potato seed production in the district of the Hannover chamber of agriculture from 1980 1996. Gesunde Pflanzen 50:107-111

Schaefer HM, Rolshausen (2007) Aphids do not attend to leaf colour as visual signal, but to the handicap of reproductive investment. Biol Lett 3:1-4

Serrano L, Filella I, Peñuelas J (2000) Remote sensing of biomass and yield of winter wheat under different nitrogen supplies. Crop Sci 40:723-731

Shull CA (1929) A spectrophotometric study of reflection of light from leaf surfaces. Bot Gazette 87:583-607

Siddiqi A, Cronin TW, Loew ER, Vorobyev M, Summers K (2004) Interspecific and intraspecific views of color signals in the strawberry poison frog Dendrobates pumilio. J Exp Biol 207:2471-2485

Sinkkonen A (2006) Do autumn leaf colours serve as a reproductive insurance against sucking herbivores? Oikos 113:557-562

Smith J (1976) Influence of crop backgrounds on aphids and other phytophagous insects on Brussels sprouts. Ann Appl Biol 83:1-13

Stadler B, Michalzik B, Müller T (1998) Linking aphid ecology with nutrient fluxes in a coniferous forest. Ecology 79:15141525

Stavenga DG, Smits RP, Hoenders BJ (1993) Simple exponential functions describing the absorbance bands of visual pigment spectra. Vision Res 33:1011-1017
Sylvester ES (1989) Viruses transmitted by aphids. In: Minks AK, Harrewijn P (eds) Aphids - their biology, natural enemies and control. Elsevier, Amsterdam, pp 65-88

Tamm CO (1951) Seasonal variation in composition of birch leaves. Physiol Plantarum 4:461-469

Thieme T, Steiner H, Busch T (1994) Vergleich der Blattlausfänge in verschiedenen Gelbschalen. Nachrichtenblatt des Deutschen Pflanzenschutzdienstes 46:65-68

Troje N (1993) Spectral categories in the learning behaviour of blowflies. Z Naturforschung 48c:96-104

Vishnevskaya TM, Shura-Bura TM (1990) Spectral sensitivity of photoreceptors and spectral inputs to the neurons of the first optic ganglion in the locust (Locusta migratoria). In: Gribakin FG, Wiese K, Popov AV (eds) Sensory systems and communication in arthropods. Birkhäuser Verlag, Basel, pp 387-394

Wimp GM, Whitham TG (2001) Biodiversity consequences of predation and host plant hybridization on an aphid-ant mutualism. Ecology 82:440-452

Wyman JA, Toscano NC, Kido K, Johnson H, Mayberry KS (1979) Effects of mulching on the spread of aphid-transmitted watermelon mosaic virus to summer squash. J Econ Entomol 72:139-143

Yang EC, Lin HC, Hung YS (2004) Patterns of chromatic information processing in the lobula of the honeybee, Apis mellifera L. J Insect Physiol 50:913-925

Yoltas T, Baspinar H, Aydin AC, Yildirim EM, Economou AS, Read PE (2001) The effect of reflective and black mulches on yield, quality and aphid populations on processing tomato. Acta Horticult 616:267-270

Ždárek J, Pospíšil J (1966) On the visual orientation of Aphis fabae Scop. to coloured lights. Acta Entomol Bohemos 63:17-24 